\title{
Research on Delay Risks of EPC Hydropower Construction Projects in Vietnam
}

\author{
Mai Sy Hung1,2*, Jianqiong Wang1 \\ ${ }^{1}$ School of Economics and Management, Southwest Jiaotong University, Chengdu, China \\ ${ }^{2}$ Water Construction Department, University of Civil Engineering, Hanoi, Vietnam \\ Email: *maihungdvh@gmail.com
}

Received 11 March 2016; accepted 18 April 2016; published 21 April 2016

Copyright (C) 2016 by authors and Scientific Research Publishing Inc.

This work is licensed under the Creative Commons Attribution International License (CC BY). http://creativecommons.org/licenses/by/4.0/

c) (i) Open Access

\begin{abstract}
In recent years, in Vietnam, economy has been developing rapidly. To ensure rapid and sustainable economic growth, strong support from the energy sector is required. Governments in Vietnam have invested in numerous hydropower projects, many of which employ the EPC (Engineering, Procurement and Construction) contract. However, the EPC general contractors are facing many difficulties, resulting in schedule delays and considerable losses. This research is conducted to highlight the main risk factors in the delays of hydropower construction projects in Vietnam. The research employs the method of statistical calculations and risk analysis to obtain feedback from experts participating in similar projects. The research outcomes are as follows: identifying the risks that can cause delays in EPC hydroelectric construction projects in Vietnam; calculating and classifying the degree of impact of each risk to the progress of the construction. The practical significance of this study is to ensure the timely completion of projects, benefits for the investors, and the EPC general contractors.
\end{abstract}

\section{Keywords}

Engineering, Procurement and Construction (EPC), Risk Research, EPC Hydropower Project, Construction Projects

\section{Research Context and Proposed Research Orientation}

\subsection{Research Context}

The EPC contract of the hydropower projects in Vietnam is facing many difficulties due to slow progress in construction and delay in time of completion. There are numerous factors leading to slow construction progress.

*Corresponding author. 
To identify these factors, the author analyzes the characteristics of hydropower projects combined with the opinions of experienced experts with hydropower projects in Vietnam. On this basis, hypotheses about risk models are developed.

In recent years in the Vietnam, more attention has been given to risk management of hydropower projects. For instance, Zhao Juelong (2008) [1] studied cases of EPC hydropower projects in Vietnam, proposed risk factors, and suggested ways to minimize risks and proposed management measures. Li Wei (2012) [2], through the research of the Con River hydropower station in Vietnam, showed risks in project procurement, contract construction, material purchases, risks of delays in the project, and the increased expenses in construction, Jixin Wei and Liujian Zhe, through the "The whole process of overseas engineering project risk management" [3] studied about project risks. The most general characteristics of hydropower projects following the EPC in Vietnam as follows: 1) The use of EPC in Vietnam is relatively new, and project management is poor; 2) At the construction sites, the people's culture standard is low, causing various difficulties; 3) Resettlement, land withdrawal and handover for the construction contractors are complex; 4) Hydropower equipment for the projects must be imported from abroad with complex procedures, difficult shipment, and slow assembly; 5) In Vietnam currently keep high inflation rates, which affect the purchase of required materials, machines, and equipment; 6) Natural conditions such as climate, hydrology, topography, and geological conditions lead to further complications; 7) The sub-contractors' construction capacity is poor; the domestic construction technology has low productivity, and is not up to standard; 8) The infrastructure and traffic facilities for transport are poor; machine and equipment transportation encounter many difficulties, leading to delays, etc.

In the above mentioned literature, the author finds that research on risks in hydropower projects in Vietnam is still limited. With the reality of tardy construction projects and progress delays, the author deems it urgent to conduct research on risks involved in delaying the construction progress of the hydropower project using EPC in Vietnam.

The research employs the method of statistical calculations and risk analysis to obtain feedback from experts participating in similar projects. The research outcomes as follows: identifying the risks that can cause delays in EPC hydroelectric construction projects in Vietnam; calculating and classifying the degree of impact of each risk to the progress of the construction.

\subsection{Proposal for Project Orientation}

\subsubsection{Project Orientation}

Using the public information on the Internet, television, newspapers and other documents, the author carried out on-site interviews with experts and officers participating in EPC projects. On the basis of these opinions, the author hypothesized the risk factors, and calculated statistical with SPSS and AMOS software to analyze and complete the objective: research on delay risks of EPC hydropower construction projects in Vietnam.

\subsubsection{Research Structure}

The structure of this research includes three main parts: 1) The risk hypothesis and the impacts of risks on construction schedule; 2) Calculation and inspection of risk; 3) Controlling and limiting risks.

\section{Risk Variables and Risk Model Selection}

\subsection{Risk Variables}

Through the analysis of information and consultation of experts' opinions, we summarize the characteristics of the hidden risks leading to delays in the construction progress of the hydropower projects. Based on these characteristics, the main reasons leading to the construction progress delays can be divided into the following groups: Risk from contracts (B1), Risk from politics and law (B2), Risk from technology (B3), Risk from natural conditions and social environment (B4), Risk from economy (B5), Risk from management (B6), Risks from EPC general contractors (B7). Table 1 is systematic table of risk factors.

\subsection{Selection of Variables for Risk Calculation Models}

Based on the above hypothesis of risks, the author summarized and proposed the hypothesis of the risk model affecting progress in Figure 1. 


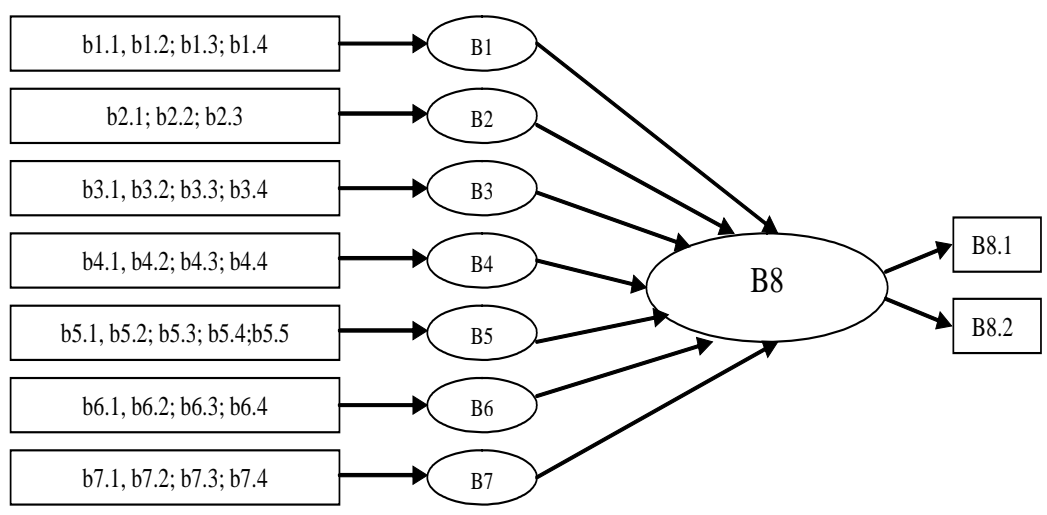

Figure 1. Specifies the assumptions of the risk system model affecting the progress.

Table 1. Hypothesis of risk group.

\begin{tabular}{|c|c|c|}
\hline $\begin{array}{l}\text { Objective for } \\
\text { evaluation }\end{array}$ & $\begin{array}{c}\text { Risk group level } 1 \\
\text { (Hidden risk cause } \\
\text { variables) }\end{array}$ & $\begin{array}{c}\text { Risks level } 2 \\
\text { (Hypothesized risk variables) }\end{array}$ \\
\hline \multirow{8}{*}{$\begin{array}{l}\text { Delaying the } \\
\text { construction progress }\end{array}$} & $\begin{array}{l}\text { Risk from contracts } \\
\text { (B1) }\end{array}$ & $\begin{array}{c}\text { Unfair contract terms (b1.1) } \\
\text { Uncertain and unclear contract terms (b1.2) } \\
\text { Fixing the EPC contract price (b1.3) } \\
\text { Second language contracts with misleading clauses (b1.4) }\end{array}$ \\
\hline & $\begin{array}{l}\text { Risk from politics and law } \\
\text { (B2) }\end{array}$ & $\begin{array}{c}\text { The relationship of investor, general contractor with the authority and relevant } \\
\text { departments (b2.1) } \\
\text { Regional political change (b2.2) } \\
\text { Laws and regulations of the management agencies (b2.3) }\end{array}$ \\
\hline & Risk from technology (B3) & $\begin{array}{c}\text { Technical design (b3.1) } \\
\text { Negative survey data (b3.2) } \\
\text { Construction drawings (b3.3) } \\
\text { Inspection of technical and drawings design (3.4) }\end{array}$ \\
\hline & $\begin{array}{l}\text { Risk from natural } \\
\text { conditions } \\
\text { and social environment } \\
\text { (B4) }\end{array}$ & $\begin{array}{c}\text { Geology, topography, and hydrography (b4.1) } \\
\text { Ethnic groups and religions (b4.2) } \\
\text { Transportation outside of the construction site (b4.3) } \\
\text { Safety and security (b4.4) }\end{array}$ \\
\hline & $\begin{array}{l}\text { Risk from economy } \\
\text { (B5) }\end{array}$ & $\begin{array}{c}\text { Finances of the investor (b5.1) } \\
\text { Interest rate fluctuations (b5.2) } \\
\text { Inflation (b5.3) } \\
\text { Financial capacity of EPC general contractors (b5.4) }\end{array}$ \\
\hline & $\begin{array}{l}\text { Risk from management } \\
\text { (B6) }\end{array}$ & $\begin{array}{c}\text { Poor progress management (b6.1) } \\
\text { Construction projects monitoring team (b6.2) } \\
\text { Poor quality work requiring repair (b6.3) } \\
\text { Construction safety (b6.4) } \\
\text { Inharmonious management among the EPC general contractors (b6.5) }\end{array}$ \\
\hline & $\begin{array}{l}\text { Risk from EPC general } \\
\text { contractors (B7) }\end{array}$ & $\begin{array}{c}\text { Purchasing materials, supplies, equipment and machines (b7.1) } \\
\text { Difficulties with subcontractors (b7.2) } \\
\text { Equipment installation and commissioning (b7.3) } \\
\text { Poor construction from the EPC general contractors (b7.4) }\end{array}$ \\
\hline & $\begin{array}{l}\text { Consequences of the risk } \\
\text { factors (B8) }\end{array}$ & $\begin{array}{l}\text { Prolong the construction progress (b8.1) } \\
\text { Increase in construction costs (b8.2) }\end{array}$ \\
\hline
\end{tabular}

\section{Calculation and Verification of the Hypothesis Model}

\subsection{Data and Supporting Software}

From the hypothesis of risks in Table 2, the author did an investigation using slips with 5 levels of risk assessment as follows. 
Table 2. Investigation using slips with 5 levels of risk assessment.

\begin{tabular}{|c|c|c|c|c|c|}
\hline \multirow{2}{*}{ 1) Risk factors and risk consequences } & \multicolumn{5}{|c|}{ Impact level of construction progress delays } \\
\hline & Low (1) & Rather low (2) & Medium (3) & High (4) & Very high (5) \\
\hline \multicolumn{6}{|l|}{ Risk factors of risk group at level 2} \\
\hline 2) Consequences of risk factors & $<10 \%$ & $10 \%-20 \%$ & $20 \%-30 \%$ & $30 \%-40 \%$ & $>40 \%$ \\
\hline
\end{tabular}

\subsection{Verification Results}

\subsubsection{Calculate the Cronbach's Alpha Reliability Coefficient}

The Cronbach's Alpha coefficient value $(\alpha)$ in the interval from 0 - 1, if $\alpha<0.6$ is insufficient reliability. In the survey data for research, we can use $\alpha>0.6$ achieved reliability, can use for analysis, (Hair J F, Anderson R E 1998) [4]; (Slater 1995) [5]. Using SPSS software to conduct the calculations and testing, the author eliminated the variables with "Corrected Item-Total Correlation" <0.3) [4]-[12] (eliminated the variables: b1.1, b1.4, b2.2, b4.2, b5.2, b6.3, b6.4, b6.5, b7.4). The Cronbach’s Alpha was then calculated, results in Table 3.

The Cronbach's Alpha coefficient $\alpha>0.6$, which holds enough reliability to permit the use of the survey results [4] [5]. After eliminating the unqualified variables, the results are as shown in Table 3.

\subsubsection{Calculate and Analyze the Discovery Factors}

Before performing the SEM model simulation, it is necessary to conduct the calculation and analysis of the discovery factors, investigate the main factors, including the observation variables (survey questions), and test the reliability as shown in Table 4. In the factor analysis of SPSS, the factor deduction method "Principal Axis Factoring” and the horizontal rotation method, Promax, were used.

The results are required to obtain a KMO $\geq 0.5$ (Hair et al., 2006) [6], testing coefficient with the statistical meaning Bartlett (Sig < 0.05) (Hair et al., 2006) [6].

The results shown in Table 4, the KMO test coefficient features the value of 0.705 ( $>0.5)$, and the coefficient with the Bartlett statistical meaning of (Sig $<0.05$ ). This proves the survey results have reliability; the question hypotheses are reasonable; the survey data is proper, and objective. The data is sufficient for conducting analysis in the following steps. Additionally, each variable features the factor loading coefficient larger than 0.5; Jabnoun \& Al-Tamimi (2003) [7] providing that the factor loading coefficient of the variables is not less than 0.3, Gerbing \& Anderson (1988) [8] clarifies the percentage of variance higher than 50\%. Initially, the author used 18 variables, based on the standard of the factor loading coefficient larger than 0.5. The author gradually deleted the variables b3.2, then the factors analysis was conducted. Seven factors were chosen, B1, B2, B3, B4, B5, B6, B7, whose percentage of variance reached $56.5 \%$, higher than the standard value of 50\%, as shown in Table 5 .

\subsubsection{Calculate and Analyze the Factors}

\section{Analyze and verify the combination of factors}

The author used the AMOS20.0 software for 8 assumption factors and 19 assumption risk variables to calculate the standardized factor loading coefficient of the 19 assumption risk variables in the interval of 0.501 to 1.038 (Table 6). In accordance with the standard factor loading coefficient $>0.5$, which shows the assumption risk variables for the groups of combined factors in a close relationship; the hypothesized risk variables have the largest effect on the factors group, as pointed out in the model.

Calculate verify the efficiency of the factors

The reliability value of the CR combination of the minimum factor is 0.75 . All values are larger than the standard coefficient of 0.5 [4], proving that the assumption variables compared with the assumption variables models is highly consistent. The author calculated the Average Variance Extracted, AVE, found the abnormal average values, and conducted the confirmation of convergence of assumption variables in the model. The result showed the AVE value is 0.51 to 0.74 , All values are larger than the standard coefficient of 0.5 [9], proving the assumption variables compared with the factors with good convergence.

\section{Verify the proposed model}

Shown in Figure 2 and from the following Table 7, it is possible to conclude that the assessment result is 


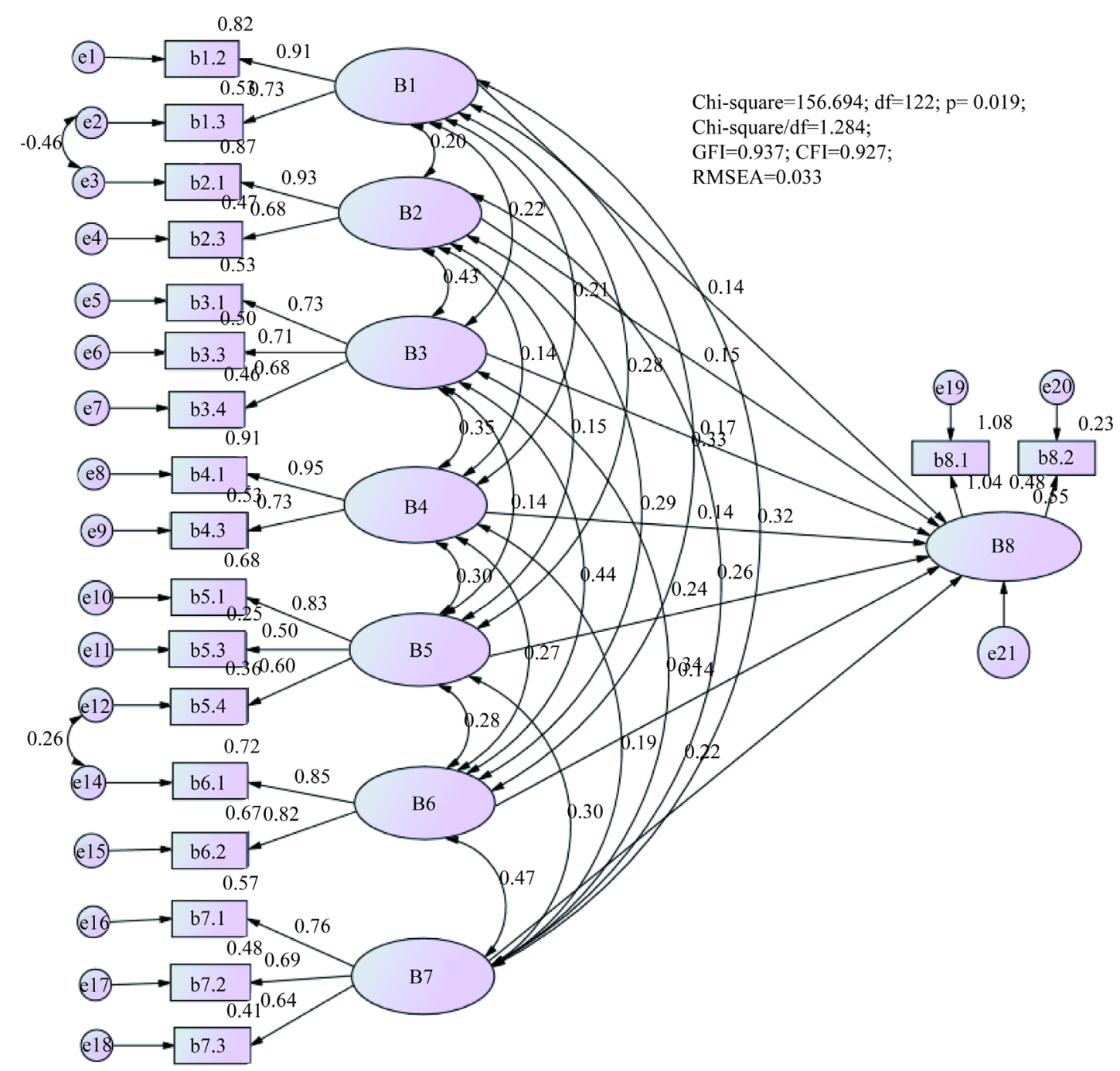

Figure 2. The structure of SEM model and assessment result.

Table 3. Cronbach’s Alpha.

\begin{tabular}{|c|c|c|c|c|c|c|c|c|c|}
\hline $\begin{array}{l}\text { Group of hidden } \\
\text { cause variables }\end{array}$ & $\begin{array}{l}\text { B1 } \\
\text { (b1.2; } \\
\text { b1.3) }\end{array}$ & $\begin{array}{c}\text { B2 } \\
\text { (b2.1; } \\
\text { b2.3) }\end{array}$ & $\begin{array}{c}\text { B3 } \\
\text { (b3.1; b3.2; } \\
\text { b3.3; b3.4) }\end{array}$ & $\begin{array}{l}\text { B4 } \\
\text { (b4.1; } \\
\text { b4.3) }\end{array}$ & $\begin{array}{c}\text { B5 } \\
\text { (b5.1; b5.3; } \\
\text { b5.4) }\end{array}$ & $\begin{array}{c}\text { B6 } \\
\text { (b6.1; } \\
\text { b6.2) }\end{array}$ & $\begin{array}{c}\text { B7 } \\
\text { (b7.1; b7.2; } \\
\text { b7.3) }\end{array}$ & $\begin{array}{c}\text { B8 } \\
\text { (b8.1; } \\
\text { b8.2) }\end{array}$ & $\begin{array}{l}\text { Sum of the } \\
\text { variables }\end{array}$ \\
\hline Cronbach's Alpha & 0.799 & 0.719 & 0.726 & 0.812 & 0.663 & 0.805 & 0.684 & 0.69 & 0.78 \\
\hline
\end{tabular}

Table 4. KMO and Bartlett’s Test, total variance explained.

\begin{tabular}{lrl}
\hline \multicolumn{2}{c}{ KMO and Bartlett’s Test } & \\
\hline Kaiser-Meyer-Olkin Measure of Sampling Adequacy. & 0.705 \\
& Sig. & 0.000 \\
\hline
\end{tabular}

extremely ideal; and further indicates the proposed model for the survey data is of reasonable design.

\section{Review the parameters of the model}

According to the parameters of the regression model given in Table 8, the values (p) of the assumption items are also less than 0.05 , which explains the reliability level of over $95 \%$. The risk factors strongly affected the extension of the construction progress. 
Table 5. Pattern Matrixa.

\begin{tabular}{|c|c|c|c|c|c|c|c|}
\hline & \multicolumn{7}{|c|}{ Factor } \\
\hline & 1 & 2 & 3 & 4 & 5 & 6 & 7 \\
\hline b1.2 & 0.713 & & & & & & \\
\hline b1.3 & 0.922 & & & & & & \\
\hline b2.1 & & 0.911 & & & & & \\
\hline b2.3 & & 0.651 & & & & & \\
\hline b3.1 & & & 0.855 & & & & \\
\hline b3.3 & & & 0.528 & & & & \\
\hline b3.4 & & & 0.611 & & & & \\
\hline b4.1 & & & & 0.813 & & & \\
\hline b4.3 & & & & 0.861 & & & \\
\hline b5.1 & & & & & 0.547 & & \\
\hline b5.3 & & & & & 0.655 & & \\
\hline b5.4 & & & & & 0.681 & & \\
\hline b6.1 & & & & & & 0.775 & \\
\hline b6.2 & & & & & & 0.893 & \\
\hline b7.1 & & & & & & & 0.511 \\
\hline b7.2 & & & & & & & 0.743 \\
\hline b7.3 & & & & & & & 0.691 \\
\hline
\end{tabular}

Table 6. Average variance extracted and AVE values.

\begin{tabular}{|c|c|c|c|c|}
\hline The hypothesized variables & $\begin{array}{l}\text { Factor loading } \\
\text { coefficients }\end{array}$ & $\begin{array}{l}\text { Errors of } \\
\text { variables }\end{array}$ & CR & AVE \\
\hline Risk from contracts (B1) & & & 0.85 & 0.74 \\
\hline Uncertain and unclear contract terms (b1.2) & 0.905 & 0.139 & & \\
\hline Transportation outside the construction site (b1.3) & 0.727 & 0.324 & & \\
\hline Risk from politics and law (B2) & & & 0.83 & 0.72 \\
\hline $\begin{array}{l}\text { The relationship of investor and general contractor with the authority and } \\
\text { relevant departments (b2.1) }\end{array}$ & 0.933 & 0.141 & & \\
\hline Laws and regulations of management agencies (b2.3) & 0.683 & 0.384 & & \\
\hline Risk from techniques (B3) & & & 0.75 & 0.51 \\
\hline Technical design (b3.1) & 0.727 & 0.467 & & \\
\hline Construction drawings (b3.3) & 0.705 & 0.493 & & \\
\hline Inspection of technical and drawings design (b3.4) & 0.682 & 0.502 & & \\
\hline Risk from natural conditions and social environment (B4) & & & 0.80 & 0.67 \\
\hline Geology, topography, and hydrography (b4.1) & 0.952 & 0.110 & & \\
\hline topography (b4.3) & 0.731 & 0.591 & & \\
\hline Risk from economy (B5) & & & 0.77 & 0.53 \\
\hline Finances of the investor (b5.1) & 0.827 & 0.215 & & \\
\hline Inflation (b5.3) & 0.501 & 0.458 & & \\
\hline Financial capacity of the contractors (b5.4) & 0.596 & 0.457 & & \\
\hline Risk from management (B6) & & & 0.84 & 0.72 \\
\hline Poor management of progress (b6.1) & 0.850 & 0.264 & & \\
\hline Construction items monitoring unit (b6.2) & 0.816 & 0.283 & & \\
\hline Risk from the EPC general contractors (B7) & & & 0.79 & 0.56 \\
\hline Purchasing materials, equipment, and machines (b7.1) & 0.756 & 0.287 & & \\
\hline Sub-contractor (b7.2) & 0.693 & 0.416 & & \\
\hline Equipment installation and commissioning (b7.3) & 0.636 & 0.423 & & \\
\hline Consequences of the risk factors (B8) & & & 079 & 068 \\
\hline Prolong the construction progress (b8.1) & 1.038 & 0.063 & 0.19 & 0.68 \\
\hline Increase construction costs (b8.2) & 0.501 & 0.576 & & \\
\hline
\end{tabular}


Table 7. Absolute appropriate index and information index.

\begin{tabular}{|c|c|c|c|c|c|c|c|c|}
\hline & \multicolumn{8}{|c|}{ Absolute appropriate index } \\
\hline & Chi-square/df & GFI & TLI & CFI & \multicolumn{4}{|c|}{ RMSEA } \\
\hline Value & 1.284 & 0.937 & 0.901 & 0.927 & \multicolumn{4}{|c|}{0.033} \\
\hline $\begin{array}{l}\text { Assessment } \\
\text { criteria }\end{array}$ & $\begin{array}{l}\text { Hair et al., } 1998[4] \text { think that } 1< \\
\text { Chi-square/df }<3 \text { is very good }\end{array}$ & \multicolumn{3}{|c|}{$\begin{array}{l}\text { Segar, Grover, } 1993[10] \text { and Chin, } \\
\text { Todd, think that }>0.9 \text { is very good. }\end{array}$} & \multicolumn{4}{|c|}{$\begin{array}{l}\text { Taylor, Sharland, Cronin, Bullard, } 1993[11] \\
\text { think that RMSEA }<0.05 \text { is very good }\end{array}$} \\
\hline \multicolumn{3}{|c|}{ Assumption } & \multicolumn{2}{|c|}{$\begin{array}{l}\text { Non-standardized } \\
\text { coefficients }\end{array}$} & S.E. & C.R. & $\mathrm{P}$ & $\begin{array}{l}\text { Standardized } \\
\text { coefficients }\end{array}$ \\
\hline \multicolumn{3}{|c|}{$\begin{array}{c}\text { Consequences of risks (Prolong the construction progress) } \leftarrow \\
\text { Risk from contracts (B1) }\end{array}$} & \multicolumn{2}{|c|}{0.211} & 0.087 & 2.416 & 0.016 & 0.136 \\
\hline \multicolumn{3}{|c|}{$\begin{array}{c}\text { Consequences of risks (Prolong the construction progress) } \leftarrow \\
\text { Risk from the politics and law (B2) }\end{array}$} & \multicolumn{2}{|c|}{0.236} & 0.093 & 2.528 & 0.011 & 0.146 \\
\hline \multicolumn{3}{|c|}{$\begin{array}{c}\text { Consequences of risks (Prolong the construction progress) } \leftarrow \\
\text { Risk from techniques (B3) }\end{array}$} & \multicolumn{2}{|c|}{0.236} & 0.105 & 2.245 & 0.025 & 0.167 \\
\hline \multicolumn{3}{|c|}{$\begin{array}{l}\text { Consequences of risks (Prolong the construction progress) } \leftarrow \\
\text { Risk from natural conditions and social environment (B4) }\end{array}$} & \multicolumn{2}{|c|}{0.162} & 0.064 & 2.532 & 0.011 & 0.143 \\
\hline \multicolumn{3}{|c|}{$\begin{array}{c}\text { Consequences of risks (Prolong the construction progress) } \leftarrow \\
\text { Risk from economy (B5) }\end{array}$} & \multicolumn{2}{|c|}{0.440} & 0.126 & 3.506 & $* * *$ & 0.237 \\
\hline \multicolumn{3}{|c|}{$\begin{array}{c}\text { Consequences of risks (Prolong the construction progress) } \leftarrow \\
\text { Risk from management (B6) }\end{array}$} & \multicolumn{2}{|c|}{0.173} & 0.085 & 2.037 & 0.042 & 0.139 \\
\hline \multicolumn{3}{|c|}{$\begin{array}{c}\text { Consequences of risks (Prolong the construction pro.) } \leftarrow \text { Risk } \\
\text { from the EPC general contractors (B7) }\end{array}$} & \multicolumn{2}{|c|}{0.331} & 0.111 & 2.985 & 0.003 & 0.220 \\
\hline
\end{tabular}

Note: ${ }^{* * *}$ Indicate the value less than 0.001 .

\section{Conclusions}

The work achieved includes the following:

1) Recognizing the risks existing in the EPC hydropower projects in Vietnam, thereby establishing the risk factor model for projects in Vietnam.

2) Based on those risk models, calculating, analyzing and carefully evaluating the risks to determine the 17 the main reason causes leading to the delays of construction progress of the projects.

3) Discovering the levels of risk impacts to construction progress finds that the largest risk factor is Risk from the economy (B5), which can severely delay the construction progress. The remaining factors from high to low impact level are: Risk from the EPC general contractors (B7); Risk from techniques (B3); Risk from the politics and law (B2); Risk from natural conditions and social environment (B4); Risk from the management (B6); Risk from contracts (B1).

These efforts have achieved the goals set by the original thesis: research on the risk of delay in construction of hydropower projects, Procurement and Construction (EPC) in the Vietnam.

Research results show overall objective situation EPC hydropower projects in Vietnam. Based on the results of this thesis, recommendations have been proposed regarding the full understanding of the risk factors of EPC project constructions to enhance risk management, as follows: Firstly, it is necessary to reinforce the theory of risk management, and continuously summarize and accumulate the experiences in the actual construction process to manage the risks of all similar projects. Secondly, before the construction, it is essential to consider the characteristics and circumstances of each given project, and continue to determine and assess each stage of hidden risk factors that may occur in order to control and restrain them.

\section{References}

[1] Zhao, J.L. (2008) A Brief Study on the Risk Management of the Vietuamese Hydro Power Project Contract. Enterprise Science and Technology \& Development Press, 20, 42-45. 
[2] Li, W. (2012) Study on the Risk Management for International Hydropower Engineering of EPC Program. Dalian University of Technology, Dalian.

[3] Wei, H.X. and Zhe, L.J. (2013) The Whole Process of Overseas Engineering Project Risk Management. International Economic Press, 8, 77-81.

[4] Hair, J.F., Anderson, R.E., Tatham, R.L., et al. (1998) Multivariate Data Analysis. Vol. 34, Prentice Hall, Upper Saddle River, 78-82.

[5] Slater, S. (1995) Issues in Conducting Marketing Strategy Research. Journal of Strategic, 5, 147-151. http://dx.doi.org/10.1080/09652549500000016

[6] Hair, J., et al. (2006) Multivariate Data Analysis. Prentical Hall, Upper Saddle River.

[7] Jabnoun and Al-Tamimi (2003) Measuring Perceived Service Quality at UAE Commercial Banks. International Journal of Quality and Reliability Management, 47-55.

[8] Gerbing and Anderson (1988) An Update Paradigm for Scale Development Incorporing Unidimensionality and Its Assessments. Journal of Marketing Research, 36-45.

[9] Fornell, C. and Larcker, D.F. (1981) Evaluating Structural Equation Models with Unobservable Variables and Measurement Error. Journal of Marketing Research, 18, 39-50. http://dx.doi.org/10.2307/3151312

[10] Segars, A.H. and Grover, V. (1993) Re-Examining Perceived Ease of Use and Usefulness: A Confirmatory Factor Analysis. MIS Quarterly, 17, 517-525. http://dx.doi.org/10.2307/249590

[11] Taylor, S., Sharland, A., Cronin, J. and Bullard, W. (1993) Recreational Service Quality in the International Setting. International Journal of Service Industry Management, 4, 68-86. http://dx.doi.org/10.1108/09564239310044316

[12] Pterson, R. (1994) A Meta-Analysis of Cronbach's Coefficient Alpha. Journal of Consumer Research, 21, $38-91$. http://dx.doi.org/10.1086/209405 